\title{
PEMANFAATAN LIMBAH KELAPA SAWIT PADA BEBERAPA VARIETAS SORGUM (Sorghum bicolor [L.] Moench.) YANG DIBUDIDAYAKAN DI SELA KELAPA SAWIT
}

\author{
Aswari ${ }^{1}$, Santi $\mathbf{R}^{1}$, Lestari $\mathrm{T}^{1 . a}$ \\ Program Studi Agroteknologi, Fakultas Pertanian Perikanan dan Biologi, Universitas Bangka Belitung \\ JI. Kampus Terpadu UBB, Kelurahan Balunijuk, Kecamatan Merawang, Kabupaten Bangka, \\ Provinsi Kepulauan Bangka Belitung 33172 \\ Email: trilestariubb3@gmail.com
}

Submitted : 14 Januari 2022 Accepted : 17 Januari 2022 Approved : 22 Februari 2022

\begin{abstract}
ABSTRAK
Pemanfaatan areal antara kelapa sawit telah banyak digunakan sebagai lahan untuk budidaya tanaman pertanian. Salah satu tanaman yang dapat ditanam sebagai tanaman sela pada kelapa sawit belum menghasilkan adalah sorgum. Tujuan penelitian ini adalah untuk mengetahui pengaruh limbah kelapa sawit dan varietas sorgum terhadap pertumbuhan dan hasil tanaman sorgum di lahan belum menghasilkan. Penelitian ini dilaksanakan pada lahan belum menghasilkan (TBM) kelapa sawit berumur 1,4 tahun di Desa Petaling Banjar Kecamatan Mendo Barat Kabupaten Bangka pada bulan Januari - Juni 2021. Penelitian ini menggunakan metode Rancangan Acak Kelompok (RAK) Faktorial dengan 2 (dua) faktor. Faktor pertama adalah pemanfaatan limbah kelapa sawit yang terdiri dari 3 taraf perlakuan yaitu P0 : Kontrol, P1 : TKKS dan P2 : Solid. Faktor kedua adalah penggunaan varietas sorgum yang terdiri dari 3 taraf perlakuan yaitu V1: Varietas Numbu, V2 : Varietas Super 2 dan V3 : Varietas Biogum 1. Hasil penelitian menunjukkan bahwa perlakuan limbah kelapa sawit dan varietas sorgum serta interaksinya berpengaruh terhadap bobot benih tanaman dan bobot benih per petak. Penggunaan solid dan varietas super 2 mampu meningkatkan pertumbuhan dan hasil sorgum sebagai tanaman sela kelapa sawit. Hasil penelitian ini menunjukkan bahwa sorgum varietas super 2 berpotensi untuk dibudidayakan secara tumpangsari.

Kata kunci: Sorgum, tanaman sela, limbah sawit
\end{abstract}

\section{ABSTRACT}

Utilization of the area between oil palm has been widely used as land for the cultivation of agricultural crops. One of the crops that can be planted as intercrops for immature oil palm is sorghum. The purpose of this study was to determine the effect of palm oil waste and sorghum varieties on the growth and yield of sorghum plants in immature oil palm land. This research was carried out on immature oil palm land (TBM) aged 1,4 years in Petaling Banjar Village, Mendo Barat District, Bangka Regency in January - June 2021. The study used a Factorial Randomized Block Design method with two factors. The first factor is the use of palm oil waste which consists of 3 treatment levels, namely P0: Control, P1: EFB (empty fruit bunches) and P2: Solid. The second factor was the use of sorghum varieties which consisted of 3 levels of treatment, namely V1: Numbu variety, V2: Super 2 variety and V3: Bioguma variety 1 . The results showed that the waste treatment of oil palm and sorghum varieties and their interactions had an effect on plant seed weight and seed weight per plot. The use of solid and super 2 varieties was able to increase the growth and yield of sorghum as an intercrop of oil palm. Our result suggest that sorghum variety super 2 is potential to be cultivated in intercropping.

Keywords: Sorghum, intercrops, palm waste.

\section{PENDAHULUAN}

Luas areal perkebunan kelapa sawit tahun 2018 tercatat mencapai 14.326.350 hektar. Luasan perkebunan kelapa sawit tersebut, sebagian besar diusahakan oleh Perusahaan Besar Swasta (PBS) yaitu sebesar $55,09 \%$ atau seluas 7.892 .706 hektar, Perkebunan Rakyat (PR) yaitu sebesar 5.818 .888 hektar atau $40,62 \%$ sedangakan Perkebunan Besar Negara (PBN) yaitu
614.756 hektar atau 4,29\% (Direktur Jenderal Perkebunan 2018).

Lahan kebun tanaman kelapa sawit belum menghasilkan (TBM) pada umumnya merupakan hamparan dengan penggunaan lahan sekitar $15-20 \%$, selebihnya adalah hamparan kosong yang merupakan gawangan belum ternaungi sempurna, karena pertumbuhan daun tanaman belum menutupi seluruh areal lahan (Simanulang dan Idwar 2019). Menurut Sutarta et al., (2012), periode pemanfaatan lahan kelapa sawit untuk 
tanaman sela dengan tanaman tumpangsari disarankan tanaman berumur 2 tahun (TBM 2) dengan pertimbangan pertumbuhan tanaman kelapa sawit dan perawatan tanaman kelapa sawit mulai intensif.

Pemanfaatan areal antara kelapa sawit telah banyak digunakan sebagai lahan budidaya tanamana pertanian. Salah satu tanaman yang dapat ditanam sebagai tanaman sela kelapa sawit belum menghasilkan adalah sorgum. Sorgum (Sorghum bicolor (L.) Moench) merupakan tanaman yang cocok ditanam di daerah kering dan memiliki adaptasi tinggi terhadap curah hujan rendah (Soni et al., 2017). Sorgum memiliki potensi untuk dikembangkan di Indonesia karena kemampuan adaptasi tanaman sorgum dapat tumbuh di lahan suboptimal. Lestari et al (2014) bahwa sorgum mampu tumbuh di lahan suboptimal seperti lahan tanah masam. Sorgum memiliki kandungan nutrisi yang tinggi, bahkan kadar proteinnya lebih tinggi daripada beras. Sorgum memiliki kadar protein $11 \%$, sedangkan beras hanya $6,8 \%$. Kandungan nutrisi mikro lain yang dimiliki oleh sorgum adalah kalium, besi, fosfor, serta vitamin B (Subagio dan Aqil 2014).

Hasil penelitian Herman dan Pranowo (2010) di Bagan Sapta Permai, kabupaten Rokan Hilir, Riau. Produksi tanaman sela jagung per hektar pertanaman kelapa sawit yang sedang diremajakan ini setara dengan produksi jagung pipilan kering 4,6 ton per hektar pada pertanaman sawit TBM. Berdasarkan penelitian Agustira et al (2018) bahwa penanaman jagung dan kedelai memiliki produktivitas $95 \%$ dan $85 \%$ dibandingkan dengan tanaman monokultur dan menunjukkan bahwa jagung dan kedelai sebagai tanaman sela yang lebih efisien pada lahan TBM dengan luasan yang sama.

Upaya untuk meningkatkan produktivitas tanaman sorgum di sela tanaman kelapa sawit belum menghasilkan (TBM) perlu adanya pemberian bahan organik. Menurut Widodo et al. (2018) pengguanaan bahan organik dapat membentuk struktur tanah yang lebih stabil. Limbah hasil produksi kelapa sawit merupakan jenis bahan organik yang telah banyak digunakan dalam bidang pertanian. Menurut penelitian Oktaviani et al (2020) pemberian limbah kelapa sawit sebagai amelioran mampu meningkatkan sifat fisik serta meningkatkan kadar bahan organik tanah. Menurut Pandapotan et al. (2017) pemberian limbah sawit seperti abu boiler, kompos TKKS, dan solid dapat meningkatkan $\mathrm{pH}, \mathrm{C}$-oragnik, dan $\mathrm{P}$ tersedia dalam tanah.
Provinsi Bangka Belitung terdapat banyak perkebunan kelapa sawit yang mana sela atau lorongan tanaman kelapa sawit belum dimanfaatkan secara optimal, sehingga perlu adanya penelitian tentang pemanfaatan lahan sela kelapa sawit dengan pemberian limbah kelapa sawit sebagai bahan organik. Melalui penelitian ini agar lahan sela pada kelapa sawit belum menghasilkan (TBM) dapat dimanfaatkan secara optimal sebagai lahan budidaya tanaman pertanian.

Tujuan penelitian ini untuk mengetahui pengaruh limbah kelapa sawit dan varietas sorgum terhadap pertumbuhan dan hasil tanaman sorgum dilahan kelapa sawit belum menghasilkan.

\section{METODOLOGI PENELITIAN}

Penelitian ini dilaksanakan pada bulan Januari 2021 sampai Juni 2021 di lahan kelapa sawit belum menghasilkan (TBM) umur 1,4 tahun di Desa Petaling Banjar, Kecamatan Mendo Barat, Kabupaten Bangka, Provinsi Kepulauan Bangka Belitung. Alat yang digunakan dalam penelitian terdiri dari golok, pisau, meteran, tali, paku, ember, bambu, cangkul, timbangan, cetok, kamera dan alat tulis. Bahan yang digunakan antara lain pupuk anorganik, benih sorgum varietas numbu, sorgum varietas super 2 , sorgum varietas bioguma 1 dan furadan.

Penelitian ini menggunakan metode Rancangan Acak Kelompok (RAK) Faktorial yang terdiri dari 2 faktor perlakuan. Faktor pertama adalah penggunan limbah kelapa sawit, dan Faktor kedua adalah jenis varietas tanaman sorgum. Faktor pertama, penggunaan limbah kelapa sawit terdiri 3 taraf perlakuan yang diuji, yaitu P0 : Kontrol, P1 : TKKS dan P2 : Solid. Faktor kedua, jenis varietas tanaman sorgum terdiri 3 taraf perlakuan yang diuji, yaitu V1 : Varietas Numbu, V2 : Varietas Super 2 dan V3: Varietas Bioguma 1

Terdapat 9 kombinasi perlakuan, setiap kombinasi perlakuan diulang $3 \mathrm{kali}$, sehingga diperoleh 27 unit percobaan, dalam satu petakan terdapat 24 tanaman sehingga terdapat 648 populasi tanaman. Unit percobaan terdiri dari 6 tanaman sampel sehingga total sampel tanaman berjumlah 162 tanaman.

Tahap awal dari penelitian adalah Persiapan Lahan. Lahan yang digunakan adalah lahan perkebunan kelapa sawit yang belum menghasilkan (TBM). Persiapan lahan meliputi pengukuran lahan, pembersihan lahan dari gulma yang dapat menghambat pertumbuhan tanaman dan pengolahan lahan berupa pembuatan petak atau bedeng. Lahan 
yang sudah dibuat petakan kemudian dilakukan pembuatan saluran drainase. Petak dibuat dengan ukuran $2 \mathrm{~m} \times 2 \mathrm{~m} /$ petak. Jarak antar petak $2 \mathrm{~m}$. Luas lahan yang akan dijadikan tempat penelitian yaitu $34 \mathrm{~m} \times 27 \mathrm{~m}$.

Aplikasi Limbah Kelapa Sawit berupa TKKS (Tandan Kosong Kelapa Sawit) dan Solid. Pengaplikasian limbah kelapa sawit dilakukan 7 hari sebelum penanaman. Banyaknya bahan limbah kelapa sawit yang diaplikasikan yaitu kompos TKKS 20 ton/ha dan 30 ton/ha. Limbah kelapa sawit sebagai bahan organik ditimbang sesuai dengan dosis anjuran dengan cara ditabur secara merata pada masing-masing petak pengamatan sesuai perlakuan yang ada (Oktaviani et al 2020).

Persiapan Bahan tanam diperoleh dari benih yang bagus, untuk mendapatkan benih yang bagus benih harus direndam dengan air \pm 1 jam. Benih yang bagus memiliki ciri-ciri akan tenggelam dalam air dan yang kurang bagus akan mengapung diatas air, sehingga benih yang tenggelam dijadikan sebagai bahan tanam.

Penanaman Benih Sorgum dilakukan dengan cara memasukkan 1 biji sorgum ke dalam lubang tanam, kemudian lubang tanam ditutup dengan tanah di sekitar lubang tanam. . Jarak tanam yang digunakan $75 \mathrm{~cm} \times 20 \mathrm{~cm}$ (Tabri dan Zubachtirodin 2016).

Pemeliharaanm tanaman meliputi penyiraman, penyulaman, pemupukan, pengendalian hama dan penyakit serta penyiangan gulma. Penyiraman dilakukan sehari dua kali pada pagi hari dan sore hari. Penyulaman tanaman sorgum dilakukan dengan cara mengganti tanaman yang mati dengan tanaman yang memiliki umur tidak lebih dari 14 hari setelah tanam (HST). Pengaplikasian pupuk dilakukan pada 14 hari setelah tanam (HST) menggunakan pupuk kimia yaitu Urea $50 \mathrm{~kg} / \mathrm{ha}$, Sp-36 $50 \mathrm{~kg} / \mathrm{ha}$ dan $\mathrm{KCL} 50 \mathrm{~kg} / \mathrm{ha}$. Pengendalian hama dan penyakit dilakukan dengan cara fisik dan kimia. Pengendalian gulma dilakukan secara mekanis menggunakan cangkul atau menggunakan tangan pada sekitaran tanaman.

Pamanenan dilakukan setelah tanaman sudah siap di panen dan sudah masuk matang secara fisiologis. Penentuan waktu panen untuk sorgum diidentifikasi dengan melihat visual karakteristik biji. Pemanenan juga bisa dilakukan setelah muncul cirri-ciri tanaman seperti daun menguning dan mengering (Lestari et al 2019).

Parameter yang diamati dalam penelitian ini adalah tinggi tanaman $(\mathrm{cm})$, jumlah daun (helai), diameter batang $(\mathrm{cm})$, bobot brangkasan basah (g), bobot brangkasan kering (g), panjang akar $(\mathrm{cm})$, warna daun, volume akar (ml), bobol biji per tanaman ( $\mathrm{g} / \mathrm{tan})$ dan bobot biji per petak

Data yang diperoleh dianalisis menggunakan uji $\mathrm{F}$ pada taraf kepercayaan $95 \%$, apabila terdapat perlakuan yang berpengaruh nyata maka akan dilakukan uji lanjut dengan menggunakan uji DMRT (Duncan's Multiple Range Test) dengan taraf kepercayaan $95 \%$ menggunakan program Statistical Tool For Agriculture (STAR).

\section{HASIL DAN PEMBAHASAN}

Hasil analisis sidik ragam (Tabel 1) menunjukan bahwa perlakuan limbah kelapa sawit berpengaruh tidak nyata terhadap tinggi tanaman, jumlah daun, diameter batang, bobot brangkasan basah, bobot brangkasan kering, panjang akar, dan volume akar, serta berpengaruh nyata terhadap bobot biji per tanaman dan bobot biji per petak. Sedangkan perlakuan jenis varietas sorgum berpengaruh nyata terhadap diameter batang, bobot brangkasan basah dan bobot brangkasan kering, serta berpengaruh sangat nyata terhadap bobot biji per tanaman dan bobot biji per petak. Interaksi antara limbah kelapa sawit dan jenis varietas berpengaruh tidak nyata terhadap terhadap tinggi tanaman, jumlah daun, diameter batang, bobot brangkasan basah, bobot brangkasan kering, panjang akar, dan volume akar, serta berpengaruh sangat nyata terhadap bobot biji per tanaman dan berpengaruh nyata terhadap bobot biji per petak.

Hasil penelitian sorgum di lahan kelapa sawit belum menghasilkan menunjukkan hasil yang cukup bagus. Penelitian ini mampu meningkatkan daya guna lahan dan mampu menghasilkan pertumbuhan dan produksi sorgum dengan penambahan jenis limbah kelapa sawit. Hasil analisis sidik ragam menunjukan bahwa perlakuan limbah kelapa sawit berpengaruh nyata terhadap parameter bobot biji per tanaman dan bobot biji per petak. Hal ini disebabkan karena jenis limbah kelapa sawit yang berbeda memiliki keunggulan dan kekurangan masing-masing. Nadeak et al (2021) menyatakan bahwa limbah kelapa sawit memiliki potensi untuk menambah hara ke dalam tanah dan mampu meningkatkan kandungan bahan organik tanah untuk perbaikan sifat fisik, kimia, biologi tanah.

Tandan Kosong Kelapa Sawit (TKKS) merupakan bahan pembenah tanah yang mampu meningkatkan aktivitas mirkroorganisme dalam tanah dan memiliki kandungan unsur hara $42,8 \% \mathrm{C}, 2,90 \% \mathrm{~K}_{2} \mathrm{O}$, 
$0,80 \% \quad \mathrm{~N}, \quad 0,22 \% \quad \mathrm{P}_{2} \mathrm{O}_{5}, \quad 0,30 \% \quad \mathrm{MgO}$ serta unsur-unsur mikro antara lain $10 \mathrm{ppm} \mathrm{B}, 23$ ppm Cu dan 51 ppm Zn (Hastuti 2009). Hal ini diperkuat oleh penelitian Oktaviani et al (2020) menyatakan bahwa pemanfaatan Kompos TKKS sebagai bahan organik berpotensi memperbaiki sifat tanah secara fisik dan kimia dan Kompos TKKS mampu menyumbangkan C-organik, N, P, K, dan unsur hara lainnya dalam jumlah yang cukup tinggi.

Limbah solid merupakan salah satu limbah kelapa sawit yang dapat dimanfaatkan untuk meningkatkan pertumbuhan tanaman. Limbah solid dapat menjadi agen pembenah tanah, diharapkan dapat meningkatkan daya dukung tanah akan ketersediaan bahan organik dan unsur hara terhadap pertumbuhan tanaman (Ginting 2017). Solid mengandung unsur hara berupa nitrogen, fosfor, kalium, magnesium dan kalsium yang tinggi, sehingga dengan penambahan limbah solid yang diberikan dapat meningkatkan ketersediaan unsur hara bagi tanaman (Nanda 2019).

Tabel 1. Hasil sidik ragam penggunaan limbah kelapa sawit, jenis varietas sorgum dan interaksinya terhadap tinggi tanaman, jumlah daun, diameter batang, bobot brangkasan basah, bobot brangkasan kering, panjang akar, volume akar, hasil biji per tanaman dan hasil biji per petak

\begin{tabular}{|c|c|c|c|c|}
\hline Poubah & Limbah Sawit & Varietas & Interaksi & KK (\%) \\
\hline Peubah & $\operatorname{Pr}>f$ & $P r>f$ & $P r>f$ & $\mathrm{KK}(\%)$ \\
\hline Tinggi tanaman & $0.1285^{\text {tn }}$ & $0.5458^{\operatorname{tn}}$ & $0.0944^{\text {tn }}$ & 8.85 \\
\hline Jumah daun & $0.1050^{\operatorname{tn}}$ & $0.3670^{\operatorname{tn}}$ & $0.4176^{\text {tn }}$ & 7.72 \\
\hline Diameter batang & $0.7950^{\text {tn }}$ & $0.0224^{*}$ & $0.8393^{\text {tn }}$ & 10.49 \\
\hline $\begin{array}{l}\text { Bobot brangkasan } \\
\text { basah }\end{array}$ & $0.7428^{\text {tn }}$ & $0.0348^{*}$ & $0.5006^{\text {tn }}$ & 26.99 \\
\hline $\begin{array}{l}\text { Bobot brangkasan } \\
\text { kering }\end{array}$ & $0.7328^{\text {tn }}$ & $0.0446^{*}$ & $0.4351^{\mathrm{tn}}$ & 33.42 \\
\hline Panjang akar & $0.6845^{\mathrm{tn}}$ & $0.2117^{\mathrm{tn}}$ & $0.5225^{\text {tn }}$ & 38.67 \\
\hline Volume akar & $0.9619^{\text {tn }}$ & $0.4338^{\text {tn }}$ & $0.9559^{\text {tn }}$ & 15.35 \\
\hline $\begin{array}{l}\text { Bobot biji per } \\
\text { tanaman }\end{array}$ & $0.0225^{*}$ & $<0.0000^{* *}$ & $<0.0076^{* *}$ & 30.51 \\
\hline $\begin{array}{l}\text { Bobot biji per } \\
\text { petak }\end{array}$ & $0.0351^{\star}$ & $<0.0000^{* *}$ & $0.0135^{*}$ & 35.65 \\
\hline
\end{tabular}

Keterangan : $\mathrm{tn}=$ Berpengaruh tidak nyata, ${ }^{*}=$ Berpengaruh nyata, ${ }^{* *}=$ Berpengaruh sangat nyata, $\mathrm{KK}=$ Koefisien keragaman, $\mathrm{Pr}>\mathrm{f}=$ Nilai Probabilitas

Hasil uji lanjut DMRT berbagai jenis limbah kelapa sawit TKKS dan Solid memberikan hasil yang berbeda nyata. Perlakuan solid menunjukkaan hasil yang lebih tinggi terhadap parameter bobot biji per tanaman dan bobot biji per petak (Tabel 2).

Solid memberikan pengaruh terhadap parameter bobot biji per tanaman dan bobot biji per petak diduga limbah solid mampu menyumbang C-organik dan unsur $\mathrm{N}$ yang cukup tinggi. Menurut penelitian Bahtiar et al (2021) bahwa limbah solid memiliki kandungan C-organik sebesar $27,71 \%$, unsur $\mathrm{N}$ sebesar $1,65 \%$, unsur $\mathrm{P}$ sebesar $0,10 \%$ dan unsur $\mathrm{K}$ sebesar $2,75 \%$

Keberadaan C-organik dalam tanah dapat memicu kegiatan mikroorganisme sehingga meningkatkan proses dekomposisi tanah dan meningkatkan reaksi-reaksi yang memerlukan bantuan mikroorganisme seperti pelarutan $\mathrm{P}$ dan fiksasi $\mathrm{N}$. Menurut Afandi et al. (2015), menyatakan bahwa peningkatan Corganik dalam tanah dapat mempengaruhi sifat fisik, kimia dan biologi tanah.
Tabel 2. Hasil uji lanjut DMRT jenis limbah sawit terhadap parameter bobot biji per tanaman dan bobot biji per petak.

\begin{tabular}{ccc}
\hline \multirow{2}{*}{$\begin{array}{c}\text { Limbah } \\
\text { sawit }\end{array}$} & \multicolumn{2}{c}{ Peubah } \\
\cline { 2 - 3 } & $\begin{array}{c}\text { Bobot biji per } \\
\text { tanaman }\end{array}$ & $\begin{array}{c}\text { Bobot biji per } \\
\text { petak }\end{array}$ \\
\hline Kontrol & $17.37 \mathrm{ab}$ & $235.37 \mathrm{ab}$ \\
TKKS & $15.55 \mathrm{~b}$ & $224.20 \mathrm{~b}$ \\
Solid & $23.60 \mathrm{a}$ & $342.11 \mathrm{a}$ \\
\hline Keterangan & A & Angka-angka yang diikuti \\
& dengan huruf yang sama pada \\
& kolom dan baris yang berbeda \\
& menunjukkan tidak berbeda nyata \\
& berdasarkan DMRT pada taraf \\
& kepercayaan 95\%.
\end{tabular}

Hasil uji lanjut DMRT berbagai jenis varietas sorgum menunjukkan bahwa penggunaan varietas sorgum berpengaruh nyata terhadap parameter diameter batang, bobot brangkasan basah, bobot brangkasan kering, bobot biji per tanaman dan bobot biji per petak. Perlakuan varietas Super 2 memberikan hasil tertinggi pada parameter 
diameter batang, bobot biji per tanaman dan bobot biji per petak serta varietas Bioguma 1 memberikan hasil terbaik pada parameter bobot brangkasan basah dan bobot brangkasan kering (Tabel 3).

Hal ini diduga bahwa setiap varietas sorgum memiliki sifat genetik, keunggulan dan kekurangan masing-masing seperti menghsilkan biji, menghasilkan brangkasan dalam jumlah banyak dan ada juga yang di fase vegetatif dan generatifnya berbeda sehingga menyebabkan ada yang unggul di jumlah daun, brangkasan dan unggul di produksi. Zulkarnaen et al (2015) menyatakan bahwa perbedaan varietas yang ditanam pada lingkungan yang sama akan menghasilkan perbedaan pada komponen pertumbuhan dan hasil produksinya.
Varietas Super 2 mampu tumbuh baik dan mampu menghasilkan biji tertinggi dari varietas lainnya. Hal ini sejalan dengan penelitian Gedoan (2019) menyatakan bahwa Varietas Super 2 mempunyai bobot berat biji lebih tinggi di bandingkan varietas lainnya. Hal ini diperkuat oleh penelitian Aqil et al (2013) bahwa Varietas Super 2 mempunyai potensi hasil yang lebih tinggi dibandingkan dengan varietas Suri 3.

Varietas bioguma 1 mampu menghasilkan bobot brangkasan basah dan bobot brangkasan kering tertinggi. Hal ini sesuai dengan deskripsi tanaman sorgum bahwa varietas bioguma 1 memiliki bobot biomassa tertinggi hingga mencapai 46,08 ton/ha dari varietas lainnya (Pusat Perlindungan Varietas Tanaman dan Perizinan Pertanian 2019).

Tabel 3. Hasil uji lanjut DMRT jenis varietas terhadap parameter diameter batang, bobot brangkasan basah, bobot brangkasan kering, bobot biji per tanaman dan bobot biji per petak.

\begin{tabular}{cccccc}
\hline Varietas & $\begin{array}{c}\text { Diameter } \\
\text { batang }\end{array}$ & $\begin{array}{c}\text { Bobot } \\
\text { brangkasan } \\
\text { basah }\end{array}$ & $\begin{array}{c}\text { Peubah } \\
\text { brangkasan } \\
\text { kering }\end{array}$ & $\begin{array}{c}\text { Bobot biji per } \\
\text { tanaman }\end{array}$ & $\begin{array}{c}\text { Bobot biji } \\
\text { per petak }\end{array}$ \\
\hline Numbu & $15.75 \mathrm{~b}$ & $329.12 \mathrm{~b}$ & $103.45 \mathrm{~b}$ & $5.26 \mathrm{~b}$ & $122.61 \mathrm{~b}$ \\
Super 2 & $18.38 \mathrm{a}$ & $410.06 \mathrm{ab}$ & $148.88 \mathrm{ab}$ & $46.04 \mathrm{a}$ & $554.81 \mathrm{a}$ \\
Bioguma 1 & $16.99 \mathrm{ab}$ & $478.05 \mathrm{a}$ & $159.63 \mathrm{a}$ & $5.22 \mathrm{~b}$ & $123.60 \mathrm{~b}$
\end{tabular}

Keterangan : Angka-angka yang diikuti dengan huruf yang sama pada kolom dan baris yang berbeda menunjukkan tidak berbeda nyata berdasarkan DMRT pada taraf kepercayaan $95 \%$.

Hasil uji lanjut DMRT terhadap interaksi antara limbah kelapa sawit dan varietas sorgum menunjukkan bahwa berpengaruh nyata terhadap parameter bobot biji per tanaman dan bobot biji per petak. Kombinasi perlakuan solid + varietas super 2 menunjukkan hasil tertinggi terhadap parameter bobot biji per tanaman sebesar 60.48 dan bobot biji per petak sebesar 780.30 (Tabel 4).

Berdasarkan deskripsi tanaman sorgum varietas Numbu, Super 2 dan Bioguma 1 yang digunakan saat penelitian bahwa varietas bioguma 1 yang memiliki potensi hasil tertinggi. Varietas Numbu memiliki potensi hasil $4-5$ ton/ha, varietas super 2 memiliki potensi hasil 6,3 ton/ha dan varietas bioguma 1 memiiki potensi hasil 9,26 ton/ha (Balitsereal 2018). Hal ini berbanding terbalik pada penelitian yang dilakukan pada lahan sela kelapa sawit bahwa varietas super 2 memiliki hasil yang tertinggi. Hal ini menunjukkan bahwa adanya interaksi antara limbah solid dan varietas super 2 sehingga mampu meningkatkan hasil tanaman sorgum dilahan sela kelapa sawit. Hal ini diduga bahwa unsur hara fospat $(P)$ pada solid sangat perperan dalam pertumbuhan generatif, serta berpengaruh terhadap pembentukan buah dan biji bagi tanaman. Hal ini diperkuat oleh penelitian Jayasumarta (2012) bahwa pemberian pupuk fosfat mempengaruhi pertumbuhan dan pembentukan polong biji tanaman pada kedelai, serta mempengaruhi pembentukan buah dan pembentukan biji terutama pada tanaman.

Selain itu, unsur hara kalium (K) pada limbah solid juga berperan dalam pembentukan polong dan biji. Hal ini diperkuat oleh penelitian Hendrival et al (2014) bahwa pemberian pupuk yang mengandung unsur hara kalium dapat meningkatkan hasil tanaman seperti jumlah polong per tanaman dan bobot biji per tanaman.

Tabel 4. Hasil uji lanjut DMRT interaksi antara jenis limbah kelapa sawit dan varietas tanaman sorgum terhadap 
parameter bobot biji per tanaman dan bobot biji per petak.

\begin{tabular}{|c|c|c|c|}
\hline \multirow[b]{2}{*}{$\begin{array}{l}\text { Limbah } \\
\text { sawit }\end{array}$} & \multicolumn{3}{|c|}{ Bobot Biji per Tanaman } \\
\hline & $\begin{array}{c}\text { V1 } \\
\text { (Numbu) }\end{array}$ & $\begin{array}{c}\text { V2 } \\
\text { (Super 2) }\end{array}$ & $\begin{array}{c}\text { V3 } \\
\text { (Bioguma 1) }\end{array}$ \\
\hline $\begin{array}{c}\text { P0 } \\
\text { (Kontrol) }\end{array}$ & $4.75 \mathrm{a}$ & $41.77 \mathrm{~b}$ & $5.57 \mathrm{a}$ \\
\hline $\begin{array}{c}\mathrm{P1} \\
\text { (Kompos } \\
\text { TKKS) }\end{array}$ & $6.21 \mathrm{a}$ & $35.87 \mathrm{~b}$ & $4.58 \mathrm{a}$ \\
\hline $\begin{array}{c}\text { P2 } \\
\text { (Solid) }\end{array}$ & $4.82 \mathrm{a}$ & $60.48 \mathrm{a}$ & $5.50 \mathrm{a}$ \\
\hline \multirow{2}{*}{$\begin{array}{l}\text { Limbah } \\
\text { sawit }\end{array}$} & \multicolumn{3}{|c|}{ Bobot Biji per Petak } \\
\hline & $\begin{array}{c}\text { V1 } \\
\text { (Numbu) }\end{array}$ & $\begin{array}{c}\text { V2 } \\
\text { (Super 2) }\end{array}$ & $\begin{array}{c}\text { V3 } \\
\text { (Bioguma 1) }\end{array}$ \\
\hline $\begin{array}{c}\text { P0 } \\
\text { (Kontrol) }\end{array}$ & $103.18 \mathrm{a}$ & $466.82 \mathrm{~b}$ & $136.11 \mathrm{a}$ \\
\hline $\begin{array}{c}\mathrm{P1} \\
\text { (Kompos } \\
\text { TKKS) }\end{array}$ & $141.42 \mathrm{a}$ & $417.31 \mathrm{~b}$ & $113.86 \mathrm{a}$ \\
\hline $\begin{array}{c}\text { P2 } \\
\text { (Solid) }\end{array}$ & $123.22 \mathrm{a}$ & $780.30 \mathrm{a}$ & $120.82 \mathrm{a}$ \\
\hline \multicolumn{4}{|c|}{$\begin{array}{r}\text { Keterangan : Angka-angka yang diikuti dengan } \\
\text { huruf yang sama pada kolom dan } \\
\text { baris yang berbeda menunjukkan } \\
\text { tidak berbeda nyata berdasarkan } \\
\text { DMRT pada taraf kepercayaan } \\
95 \%\end{array}$} \\
\hline
\end{tabular}

Hasil pengamatan warna daun sorgum pada umur 60 hari setelah tanam (HST) berdasarkan buku Munsell Color Chart For Plant Tissue, warna daun dikategorikan berdasarkan nilai hue, value dan chroma. Hasil menunjukan rata-rata warna daun memiliki nilai hue semua perlakuan sama yaitu Green Yellow. Hasil rata-rata nilai value dan chroma antar perlakuan sama yaitu 5GY 4/4, sehingga tidak terdapat perbedaan nilai yang membedakannya antara nilai value dan chroma.

Hal ini diduga karena TKKS dan solid mengandung kadar nitrogen dan magnesium yang cukup bagi tanaman dan proses penyerapan hara oleh tanaman seimbang pada setiap varietas sorgum. Sehingga proses pembentukan warna hijau daun cepat dan proses fotosintesis berjalan dengan baik. Hal ini diperkuat oleh penelitian Wirawan et al. (2016) bahwa magnesium dan nitrogen mempunyai peran penting dalam sintesis klorofil, semakin tinggi tanaman menyerap magnesium dan nitrogen maka makin tinggi kadar klorofil daun.

Nugroho (2015) menyatakan bahwa nitrogen merangsang pertumbuhan tanaman dan juga memberikan warna hijau pada daun. Hal ini diperkuat oleh penelitian Irmayani (2011) menyatakan bahwa nitrogen sangat berperan dalam proses fisiologi tanaman, terutama pada fase vegetatif dan memberikan warna hijau daun.

Kombinasi perlakuan antara limbah sawit dengan varietas sorgum berpengaruh tidak nyata pada parameter tinggi tanaman, diameter batang, jumlah daun, bobot brangkasan basah, bobot brangkasan kering, volume akar dan panjang akar (Tabel 1). Perlakuan limbah solid + varietas super 2 memberikan hasil yang tertinggi pada parameter tinggi tanaman, diameter batang dan jumlah daun (Gambar 1a sampai c). Hal ini diduga karena limbah solid mengandung unsur hara dan zat organik yang tinggi yang dapat memperbaiki sifat tanah, sehingga mampu meningkatkan pertumbuhan tinggi tanaman, jumlah daun dan diameter batang.

Pahan (2008) menyatakan bahwa limbah solid mengandung unsur hara dan zat organik yang tinggi, sehingga dapat meningkatkan sifat fisik, kimia, biologi tanah dan meningkatkan pertumbuhan tanaman. Hal ini diperkuat oleh penelitian Thabrani (2011) menyatakan bahwa bahan organik yang terdapat pada solid dapat meningkatkan aktifitas biologi tanah dalam membantu proses dekomposisi. Proses dekomposisi yang baik akan meningkatkan ketersediaan hara bagi tanaman, sehingga aktifitas metabolisme terutama proses fotosintesis menjadi meningkat dan fotosintat yang dihasilkan akan ditranslokasikan untuk pertumbuhan tanaman terutama pada fase vegetatif.

Banyaknya jumlah daun diduga akan meningkatkan proses fotosintesis sehingga fotosintat yang dihasilkan dapat membantu dalam proses pertumbuhan tinggi tanaman dan diameter batang. Berdasarkan hasil penelitian Suminar et al (2017) bahwa peningkatan tinggi tanaman dan diameter batang di duga dari hasil asimiasi/fotosintat yang di trasnlokasikan pada ujung meristem untuk menghasilkan sel baru pada ujung batang.
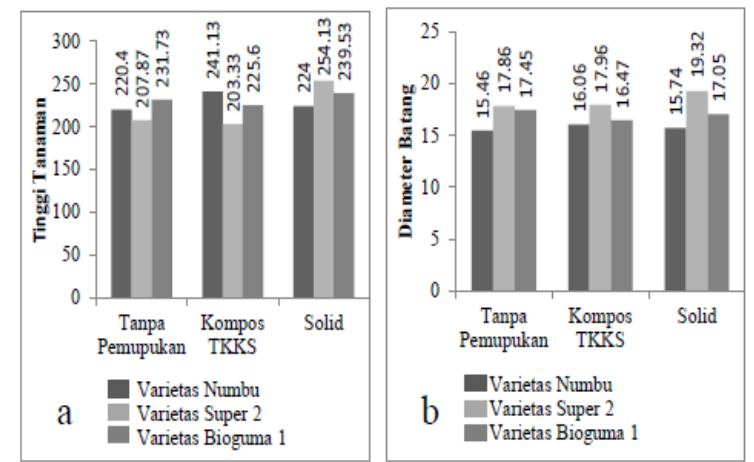


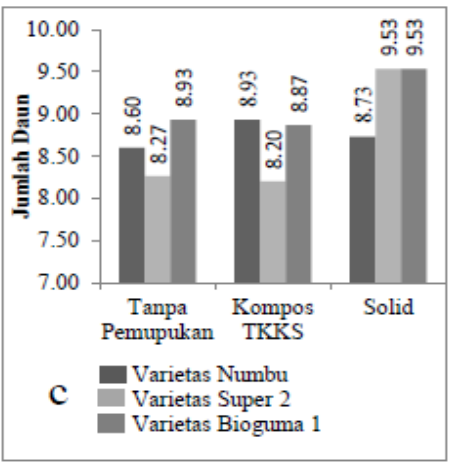

Gambar 1. Nilai rerata fase vegetatif antar kombinasi perlakuan limbah kelapa sawit dan varietas sorgum pada parameter: (a) tinggi tanaman, (b) diameter batang, (c) jumlah daun, (d) bobot brangkasan basah, (e) bobot brangkasan kering, (f) volume akar dan (g) panjang akar

Kombinasi perlakuan tanpa pemupukan (kontrol) + varietas bioguma 1 memberikan hasil yang tertinggi pada parameter bobot brangkasan basah, bobot brangkasan kering dan volume akar (Gambar 1d samapi f). Hal ini diduga bahwa pemberian limbah solid dan TKKS tidak berpengaruh pada varietas sorgum terhadap peningkatan bobot brangkasan basah, bobot brangkasan kering dan volume akar. Hal ini diduga bahwa varietas bioguma 1 mampu dalam meningkatkan bobot brangkasan basah, bobor brangkasan kering dan volume akar. Hal ini berbeda dengan penelitian Lestari et al (2021) menyataakan bahwa semakin tinggi tanaman dan semakin banyak jumlah daun maka bobot brangkasan juga akan meningkat. Menurut Efendi et al (2013) menyatakan bahwa semakin tinggi tanaman maka produksi biomassa semakin tinggi.

Kombinasi perlakuan TKKS + varietas super 2 memberikan hasil yang tertinggi pada parameter panjang akar (Gambar 1g). Hal ini menunjukkan bahwa unsur hara yang dibutuhkan tanaman dalam pembentukan dan pemanjangan akar tercukupi. Salah satu unsur hara yang berperan dalam perkembangan akar yaitu unsur hara $\mathrm{P}$ pada tandan kosong kelapa sawit (TKKS). Hal ini diperkuat oleh Pradana et al (2015) menyatakan bahwa unsur hara $P$ selain berperan sebagai energizer juga untuk memacu pertumbuhan dan perkembangan akar tanaman seperti pemanjangan, pembentukan akar halus maupun rambut akar.

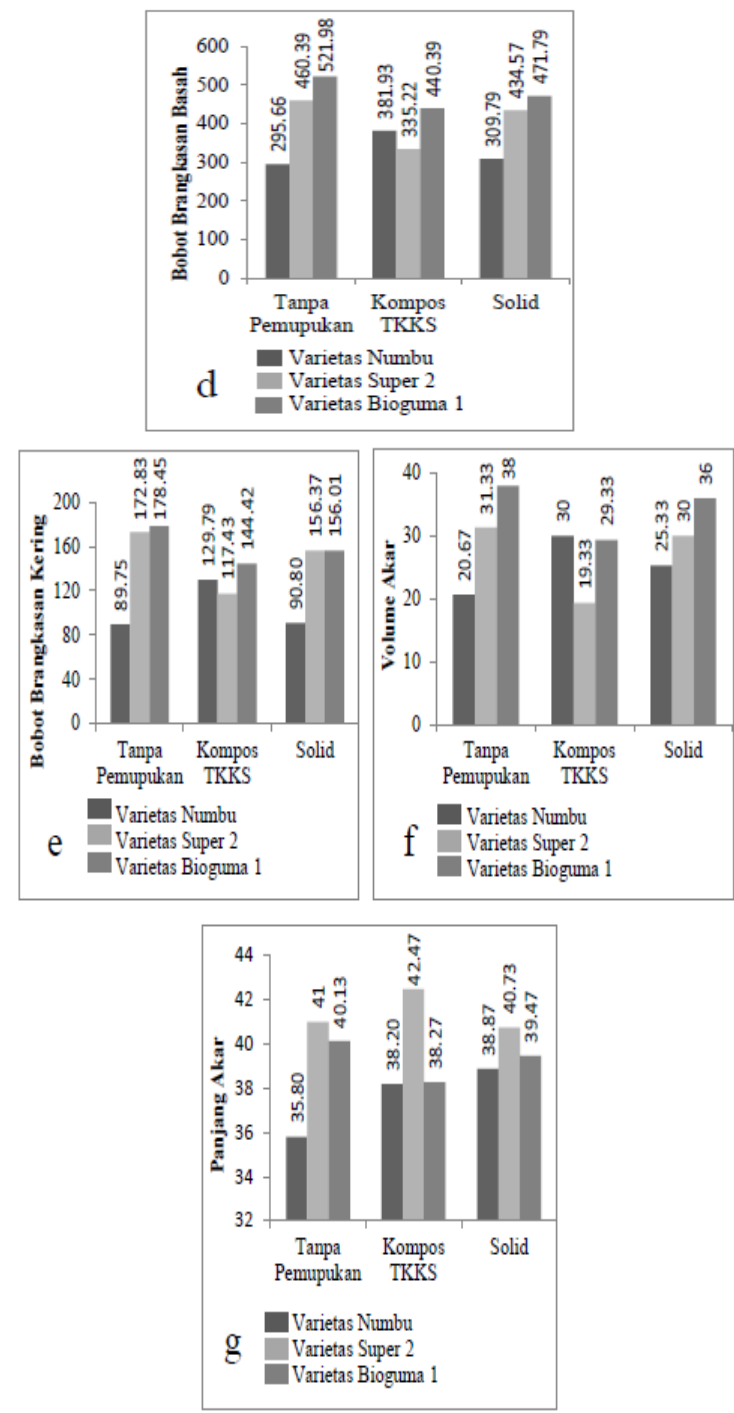

Gambar 2. Nilai rerata fase generatif antar kombinasi perlakuan limbah kelapa sawit dan varietas sorgum pada parameter: (d) bobot brangkasan basah, (e) bobot brangkasan kering, (f) volume akar dan (g) panjang akar

\section{KESIMPULAN}

1. Hasil penelitian menunjukkan bahwa perlakuan limbah kelapa sawit dan varietas sorgum serta interaksi keduannya berpengaruh terhadap bobot biji tanaman dan bobot biji per petak.

2. Penggunaan solid dan varietas super 2 mampu meningkatkan pertumbuhan dan hasil tanaman sorgum sebagai tanaman sela kelapa sawit.

3. Hasil penelitian ini menunjukkan bahwa sorgum varietas super 2 berpotensi untuk dibudidayakan secara tumpangsari. 


\section{DAFTAR PUSTAKA}

Afandi NF, Bambang Siswanto dan Yulia Nuraini. 2015. Pengaruh Pemberian Berbagai Jenis Bahan Organik Terhadap Sifat Kimia Tanah Pada Pertumbuhan dan Produksi Tanaman Ubi Jalar di Entisol Ngrangkah Pawon Kediri. Jurnal Tanah dan Sumberdaya Lahan. 2(2): 237-244.

Agustira MA, Lubis L, Eka L, Erwin NA, Iman YH, dan M. Edwin SL. 2018.Ananlisis Finansial dan Ekonomi Tanaman Sela (Jagung dan Kedelai) Pada Areal Tanaman Belum Menghasilkan Kelapa Sawit. Jurnal Pen. Kelapa Sawit. 26(3): 141-152

Aqil M, Zubachtirodin dan Raper C. 2013. Deskripsi Varietas Unggul Jagung, Sorgum dan Gandum Edisi 2013. Balai Penelitian Tanaman Serealia. Maros

Bahtiar OY, Aiyen dan Usman M. 2021. Potensi Limbah Padat Kelapa Sawit Untuk Peningkatan Pertumbuhan dan Hasil Tanaman Sorgum (Sorghum bicolor L.). e-J. Agrotekbis. 9(2): 470476

Balitsereal. 2018. Deskripsi Varietas Jagung, Gandum dan Sorgum. Balai Penelitian Tanaman Serealia, Badan Litbang pertanian. Sulawesi Selatan

Balitsereal. 2019. Varietas unggul Sorgum. Balai Penelitian Tanaman Serealia, Badan Litbang pertanian. Sulawesi Selatan

Direktur Jenderal Perkebunan. 2018. Statistik Perkebunan Indonesia 2018-2020 Kelapa Sawit

Efendi R, Aqil M dan Pabendon M. 2013. Evaluasi Genotipe Sorgum Manis (Sorghum bicolor L.) Moench) Produksi Biomassa dan Daya Ratun Tinggi. Jurnal Penelitian Pertanian Tanaman Pangan. 32(2): 116-125.

Gedoan SP. 2019. Produktivitas Sorgum Varietas Super 2 dan Suri 3 yang diberi Pupuk Anorganik dan Organik. Jurnal Sains dan Teknologi, Universitas Negeri Manado. 2(2): 121-127

Ginting, T., E. Zuhry, Adiwirman. 2017. Pengaruh Limbah Solid dan NPK Tablet Terhadap Pertumbuhan Bibit Kelapa Sawit (Elaeis guineensis Jacq.) di Pembibitan Utama.

Hastuti, P. B. 2009. Pemanfaatan Limbah Tandan Kosong Kelapa Sawit sebagai Kompos pada Tanaman Selada. Buletin Instiper, Yogyakarta.

Hendrival, Latifah dan Idawati .2014. Pengaruh Pemupukan Kalium Terhadap
Perkembangan Populasi Kutu Daun (Aphis glycines matsumura) dan Hasil Kedelai. Jurnal Floratek. 9 : 83-92.

Herman, M dan D. Pranowo. 2011. Produkivitas Jagung Sebagai Tanaman Sela Pada Peremajaan Sawit Rakyat Di Bagan Sapta Permai Riau. Balai Penelitian Tanaman Rampah dan Aneka Tanaman Industri

Irmayani, T .2011. Pengaruh Pemberian Pupuk Nitrogen Timbulnya Penyakit Daun Tanaman Jagung (Zea Mays L.) Pada Beberapa Varietas di Lapangan. [Skripsi]. Medan: Fakultas Pertanian, Universitas Sumatra Utara

Jayasumarta D .2012. Pengaruh Sistem Olahan Tanah dan Pupuk P Terhadap Pertumbuhan dan Produksi Tanaman Kedelai (Glycine max L. Merril). Jurnal Agrium. 17(3): 148-154.

Lestari T, Sopandie D, Trikoesoemaningtyas dan SW Ardie. 2014. Screening of Several Sorghum Genotypes on Acid Soil Tolerance. International Journal of Agronomy and Agriculture Research (IJAAR). 5(5): 170-176

Lestari T, Apriyadi R. dan Azan I. 2019. Optimization of Sorghum Cultivation (Sorghum Bicholor) with Ameliorant Addition in the Post-Mining of Bangka, Indonesia. International Conference on Maritime and Archipelago (ICOMA). 167: $150-153$

Lestari T, Suharyanto dan Suyipto EP. 2021. Pengaruh Dosis Pupuk Kotoran Ayam dan NPK terhadap Pertumbuhan dan Hasil Tanaman Sorgum di Lahan Pasca Tambang Timah. Jurnal IImiah dan Teknologi Pertanian, Agrosaintek. 5(2): 100-108.

Nadeak DJ, Karamoy Lientje Th dan Wiesje J.N.K .2021. Respon Pemberian Limbah Kelapa Sawit (Solid) Terhadap Tanah Marginal dengan Indikator Tanaman Bayam (Amaranthus Tricolor L.). Manado: Universitas Sam Ratulangi.

Nanda et al .2019. Pengaruh Pupuk Solid dan Zpt Auksin Terhadap Pertumbuhan Vegetatif Stek Lada (Piper nigrum L.). http://www.jurnal.una.ac.id/index.php/jb/ article/view/472/387. Diakses pada 26 November 2021.

Nugroho .2015. Penetapan Standar Warna Daun Sebagai Upaya Identifikasi Unsur Hara (N) Tanaman Jagung (Zea Mays L.) Pada Tanah Regosol. Planta Tropica Jurnal Of Agro Science. 3(1): 8-1

Oktaviani R, Suharyanto dan Tri L .2020. Respon Pertumbuhan dan Hasil Tanaman Kacang Hijau (Vigna radiata 
L.) dengan Aplikasi Limbah Sawit dan Rhizobium di Lahan Pasca Tambang Timah. Jurnal Pengkajian Dan Pengembangan Teknologi Pertanian. 23(3): 321-331

Pahan, I. 2008. Pedoman Lengkap Kelapa Sawit (Manajemen Agribisnis dari Hulu hingga Hilir). Penebar Swadaya. Jakarta

Pandapotan CD, Muklis, Marbun P. 2017. Pemanfaatan Limbah Lumpur Padat (Sludge) Pabrik Pengolahan Kelapa Sawit Sebagai Alternatife Penyediaan Unsure Hara Di Tanah Ultisol. Jurnal Agroteknologi FP Usu. 5(2): 271-276.

Pradana GBS, Islami T dan Suminarti NE. 2015. Kajian Kombinasi Pupuk Fosfat dan Kalium pada Pertumbuhan dan Hasil Dua Varietas Tanaman Sorgum (Sorghum bicolor (L.) Moench). Jurnal Produksi Tanaman. 3(6): 464-471

Pusat Perlindungan Varietas Tanaman dan Perizinan Pertanian .2019. Perlindungan Varietas Tanaman. Kementerian Pertanian. Jakarta

Simanulang, L.D dan Idwar .2019. Respon Varietas Padi Gogo Local (Oryza Sativa L.) Terhadap Pemupukan NPK Yang ditanam di Sela Tanaman Kelapa Sawit Belum Menghasilkan (TBM). Jom Faperta 6(1): 1-9

Sutarta, E.S., S. Rahutomo, Winarna, E.N. Ginting, D.Wiratmoko, R. Nurkhoiry. 2012. Sistem Peremajaan Kelapa Sawit untuk Perkebunan Rakyat. Pusat Penelitian Kelapa Sawit

Suminar R, Suwarto dan H. Purnamawati. 2017. Pertumbuhan dan Hasil Sorgum di Tanah Latosol dengan Aplikasi Dosis Pupuk Nitroggen dan Fosfor yang Berbeda. J. Agro. Indonesia. 45(3): 271277

Soni V, Kaur P, Rathore M. 2017. Sorghum bicolor (L) Moench: A model System to Study Drought Tolerance in Plants. International Journal of Food, Agriculture and Veterinary Sciences. 7(3):83-89

Subagio, H., dan M. Aqil. 2014. Perakitan dan Pengembangan Varietas Unggul Sorgum Untuk Pangan, Pakan, dan Bioenergi. Jurnal Iptek Tanaman Pangan. 9(1): 39-50..

Tabri, Fahdhiana, Zubachtirodin. 2016. Budi Daya Tanaman Sorgum. Jawa Timur: Balai Penelitian Tanaman Serealia

Thabarani, I. 2011. Bahan Organik Untuk Stabilitas Produksi Tanaman Pangan Pada Lahan Kering Podsolik. Bogor: IPB

Widodo KH, Kusuma Z. 2018. Pengaruh Kompos Terhadap Sifat Fisik Tanah dan
Pertumbuhan Tanaman Jagung di Inceptisol. Jurnal Tanah dan Sumberdaya Lahan 5(2): 959-967

Wirawan BDS, E. Tarawaca Susila Putra dan Prapto Yudono. 2016. Pengaruh Pemberian Magnesium, Boron dan Silikon terhadap Aktivitas Fisiologis, Kekuatan Struktural Jaringan Buah dan Hasil Pisang (Musa acuminata). Jurnal Vegetalika. 2016. 5(4): 1-14

Zulkarnaen, T. Irmansyah dan Irsal .2015. Respon Pertumbuhan dan Produksi Beberapa Varietas Sorgum (Sorgum Bicolor (L.) Pada Berbagai Jarak Tanama di Lahan Kelapa Sawit TBM 1. Jurnal Online Agroekoteknologi. 3(1): 328-339. 